\title{
EL COMERCIO DE LA PROVINCIA DE CORRIENTES DURANTE LA PRIMERA MITAD DEL SIGLO XIX. UN PANORAMA DE SU EVOLUCIÓN
}

\author{
Enrique César Schaller
}

\section{Introducción}

El presente trabajo pretende contribuir al mejor conocimiento de los circuitos mercantiles en la Argentina durante la etapa previa a la organización nacional. Con ese fin se analiza la evolución general del comercio exterior de Corrientes durante la primera mitad del siglo XIX. En ese lapso la economía de esa provincia experimentó grandes fluctuaciones. Tras el considerable crecimiento productivo y comercial durante el siglo XVIII una fuerte crisis afectó al sector ganadero durante la etapa revolucionaria. El nuevo equilibrio logrado en la década de 1820 pareció abrir nuevas posibilidades, sin embargo, en el desenvolvimiento de la economía rioplatense Corrientes se vio relegada un papel cada vez más marginal sobre todo a partir del largo conflicto contra Rosas en la década de 1840.

Este estudio se basa en la documentación de fiscal de la provincia. En primer lugar se ha tratado de establecer el valor monetario (en pesos plata) de las exportaciones e importaciones. A partir de los montos establecidos se busca reconstruir la evolución general de este tráfico, examinar la importancia de las vinculaciones comerciales de la provincia y composición del flujo exportador.

\section{Comercio exterior de Corrientes: fuentes para su estudio}

La evolución del comercio exterior de la provincia de Corrientes durante la primera mitad del siglo XIX puede reconstruirse a partir de las guías emitidas para la percepción de impuestos. Como es sabido, durante la etapa colonial el comercio interior en los dominios españoles estaba sujeto a diversos derechos, entre ellos estaba la alcabala, que gravaba con un 4\% ó 6\% la introducción de productos de otras jurisdicciones. Cuando se produjo el movimiento independiente las provincias perfeccionaron este sistema gravando, con una escala variable, la gran mayoría de los productos exportados e importados en su respectiva jurisdicción. Finalmente, la Constitución Nacional suprimió todos los impuestos a la circulación interior.

La ciudad de Corrientes y su distrito estuvieron hasta 1814 bajo la dependencia de Buenos Aires. Mientras duró esta subordinación las guías de la tesorería correntina registran sólo los efectos importados pues los frutos extraídos pagaban el impuesto en el lugar de destino. Esta falencia puede cubrirse en gran parte gracias al trabajo de Claudia 
Wentzel quien ha efectuado un minucioso estudio de las exportaciones del Litoral hacia Buenos Aires ${ }^{1}$

Un cambio decisivo tuvo lugar luego de la proclamación de la autonomía en el año de 1814. Corrientes se separó de Buenos Aires y pasó a integrar la "Liga de los Pueblos Libres" de Artigas. Durante la etapa artiguista se dictó el "Reglamento General Provisional" del 9 de septiembre de 1815 reformado poco después por otra resolución del 25 de abril de 1816. Ambas disposiciones constituyeron los primeros reglamentos aduaneros de la provincia. $^{2}$

Una vez desaparecida la tutela de Artigas y la de su sucesor, Francisco Ramírez, la Corrientes logró su plena autonomía (12 de octubre de 1821) e inició una etapa de organización institucional. Como parte de este proceso, durante la década de 1820 se estructuró el sistema de percepción de impuestos que, en líneas generales, perduraría hasta la desaparición de las aduanas de la provincia. ${ }^{3}$

A partir de la vigencia de los reglamentos de Artigas se cuenta información de las exportaciones pues se cobraban derechos por todos los productos que ingresaban o salían de la jurisdicción provincial. El registro completo se inicia a partir de 1816 y continúa hasta 1855 , año en que se produce la transferencia a la jurisdicción nacional. ${ }^{4}$

En las guías se consigna la cantidad de bienes comercializados (por unidad, peso o longitud en el caso de algunos cortes de madera), el destino o lugar de origen de los mismos, los comerciantes que realizan la operación y el impuesto que debía abonarse.

Si bien no hay mayores inconvenientes en establecer la cantidad de bienes involucrados, mucho más difícil es estimar su valor monetario. En este aspecto se cuenta

\footnotetext{
${ }^{1}$ Claudia Wentzel "El comercio del 'Litoral de los Ríos' con Buenos Aires: el área del Paraná 1783-1821”, Anuario IEHS, n 3, Buenos Aires, Universidad Nacional del Centro, 1988, pp. 161-210.

2 María Amalia Duarte, «Artigas y el comercio del río Paraná hasta la reunión del Congreso», Trabajos y Comunicaciones, nº 15, La Plata, 1966, pp.248-269; Hernán Félix Gómez, El general Artigas y los hombres de Corrientes, Corrientes, Imprenta del Estado, 1929, pp. 84-85.

3 José Carlos Chiaramonte, Mercaderes del Litoral. Economía y sociedad en la provincia de Corrientes, primera mitad del siglo XIX, Buenos Aires, Fondo de Cultura Económica, 1991, segunda parte, cap I.

${ }^{4}$ En el Archivo Histórico de Corrientes las guías se hallan agrupadas en dos series documentales. Los Comprobantes de Libros de Caja reúnen las guías de la aduana de la ciudad de Corrientes. Las que corresponden a las receptorías que funcionaron en otras localidades se encuentran en los Expedientes Administrativos. Comprobantes libros de Caja: legajos $\mathrm{n}^{\mathrm{o}} 1$ (1815-1818), 2 (1819-1820), 3 (1821), 4 (1822), 5-6 (1823), 7-8 (1824-1825), 9 (1826), 10-12 (1827-1828), 13-16 (1829), 17-18 (1830), 19 (1831), 20-21 (1832), 22-23 (1833), 24-28 (1834-1835)),29-31 (1836) 32-33 (1837), 34-35 (1838), 36-37 (1839), 38-39 (1840), 40-43 (1841-1842), 44-48 (1843), 47 (1844), 49-51 (1845), 52-53 (1846), 54-56 (1847). 57 60 (1849), 58-61 (1848), 62-63 (1850), 64-65 (1851), 66-68 (1852)), 69-70 (1853), 71-72 (1854), 73 (1855)

Expedientes Administrativos: legajo ${ }^{\circ} 1$ (1810-1812), 2 (1813-1816), 3 (1817), 4 (1818-1819), 5 (1820), 6 (1821), 7-8 (1822), 9-10 (1823), 11-12 (1824), 13-14 (1825), 15-18 (1826), 19-22 (1827), 23-25 (18281829), 26-29 (1830), 30-32 (1831), 33-35 (1832), 36-38 (1833), 39-42 (1834), 43-47 (1835), 48-49 (1836), 50-53 (1837), 54-57 (1838), 58 (1839), 59-60 (1840), 61-65 (1841), 66 (1842), 67-69 (1843), 70-73 (1844), 74-78 (1845), 79-85 (1846), 86-90 (1847), 90-94 (1848), 95-101 (1849), 102-105 (1850), 106-109 (1851), 110-113 (1852), 114-116 (1853), 117 (1854)
} 
con una información excepcional representada por los cálculos de la Colecturía de la provincia sobre el valor de las exportaciones e importaciones anuales que se realizaron de 1825 hasta 1841. Algunos de estos cómputos fueron publicados en su momento en el Registro Oficial pero la serie completa ha sido agrupada y analizada por José Carlos Chiaramonte en su obra "Mercaderes del Litoral".

Lamentablemente sólo se dispone de los montos totales. La consulta de la documentación de la Colecturía General no ha dado resultados que permitan conocer mejor cómo se elaboraron esos cuadros y las cifras parciales que se utilizaron. De esta manera si bien podemos seguir la evolución general del comercio en el lapso 1825-1841 no es posible determinar la participación de los bienes en el total o la importancia del tráfico con las diferentes comarcas. A esto hay que agregar que no existe información similar sobre el valor del comercio para los períodos de 1816-1824 y el de 1842-1855.

Los trabajos de Wentzel, Schmit y Rosal han permitido construir una serie sobre el valor de las exportaciones del Litoral argentino hacia Buenos Aires que abarca de 1783 a 1850. Dada la significación de la plaza porteña, los cálculos efectuados por estos autores tienen excepcional importancia para conocer la evolución general del comercio Corrientes en el contexto rioplatense. No obstante, dado que el tema central es la vinculación con Buenos Aires, la serie no incorpora datos sobre el tráfico correntino con otras comarcas. Asimismo, en la visión de conjunto que proponen los autores se ha dado especial énfasis, como es lógico, al comercio de los cueros por lo que existen menos referencias sobre la participación de los otros frutos que integraban las exportaciones locales. ${ }^{5}$

De manera similar a los sistemas impositivos de las otras provincias, en Corrientes los bienes estaban gravados por impuestos proporcionales según su valor de plaza o por derechos específicos, es decir una cantidad fija por unidad de medida. En el primer caso, la guía contiene un dato de gran importancia que es el aforo, es decir, el cálculo del precio corriente del producto.

En lo que respecta a las importaciones, el valor de las mismas es fácil de determinar pues casi todos los bienes estaban sujetos al pago de un derecho proporcional. Por otra parte debía abonarse un impuesto adicional de eslingaje que representaba el medio por ciento del monto total introducido.

\footnotetext{
${ }^{5}$ Claudia Wentzel, op. cit., Miguel A. Rosal «El Río de la Plata en la primera mitad del siglo XIX: las relaciones comerciales entre el Interior y Buenos Aires, 1831-1835», Boletín del Instituto de Historia Argentina y Americana «Dr. Emilio Ravignani», Tercera Serie, $n^{\circ}$ 5, Buenos Aires, $1^{\circ}$ semestre de 1992; Roberto Schmit, «Mercados y flujos comerciales en los Estados provinciales argentinos de la primera mitad del siglo XIX. El comercio de Corrientes a Buenos Aires (1822-1833), Boletín del Instituto de Historia Argentina y Americana «Dr. Emilio Ravignani», Tercera Serie, $\mathrm{n}^{\circ}$ 4, Buenos Aires, $2^{\circ}$ semestre de 1991; Miguel A. Rosal «El interior frente a Buenos Aires. Flujos comerciales e integración económica (18311850)», Cuadernos del Instituto de Historia Argentina y Americana «doctor Emilio Ravignani, ${ }^{\circ} 9$, Buenos Aires, 1995; Roberto Schmit «Comercio y mercado en el Litoral argentino durante la primera mitad del siglo XIX», Cuadernos del Instituto de Historia Argentina y Americana «Doctor Emilio Ravignani», $\mathrm{n}^{\circ}$ 9, 1995; Miguel A. Rosal y Roberto Schmit «De la colonia a la independencia. El comercio del Litoral argentino a Buenos Aires entre 1783 y 1850», Cuadernos del Instituto de Historia Argentina y Americana «Doctor Emilio Ravignani», nº 9, 1995.
} 
En el caso de las exportaciones este cálculo es más complicado, Si bien existía un impuesto general del 4\%, los artículos más valiosos del comercio exterior correntino, los cueros, suelas, maderas, tabaco y animales en pie, estaban sujetos a impuestos específicos. Las guías del período 1825-1836 prácticamente no ofrecen referencias sobre el valor de esos productos. A partir de 1837 la documentación se vuelve mucho más rica pues quedaron sujetos a aforo el tabaco y las maderas. Más tarde durante la década de 1840 muchos frutos paraguayos se exportaban por Corrientes y abonaban un derecho de tránsito del $2 \%$. Así se aforaron productos similares a los correntinos como el cuero, suelas y animales en pie.

Las lagunas sobre el valor de los productos sonmuydifícilesdecubrir satisfactoriamente con referencias provenientes de otras fuentes ${ }^{6}$.

Debido a estas falencias, con las guías locales sólo es posible efectuar una estimación aproximada sobre el valor de los frutos no aforados. Para establecerlo, en este trabajo se considera que el impuesto específico representaba $1 / 8$ (12,5\%) del valor de esos bienes. Esta es al menos la proporción que puede determinarse en relación con los precios corrientes de los artículos (cueros, animales en pie) que más frecuentemente aparecen en los inventarios y algunas transacciones al por mayor del gobierno. Los derechos fijos de aquellos bienes tenían algún proceso de elaboración, como los cueros curtidos, representarían el $6,25 \%$ o un 1/16 del valor. La utilización de estos valores de referencia, por supuesto, constituye sólo un instrumento alternativo de análisis ante la falta de datos sobre los precios reales.

En este trabajo para el análisis de la evolución la balanza comercial se han utilizado las cifras globales de la Colecturía para el período 1825-1841 y cálculos propios para los lapsos de 1816-1824 y 1842-1855. El estudio sobre composición de las exportaciones y las vinculaciones mercantiles se basa en todos los casos en los valores estimados

\section{Evolución general del comercio correntino}

Durante los dos primeros siglos del dominio español el comercio de Corrientes era muy limitado pues se ubicaba al margen de los principales circuitos mercantiles de la época y sobre todo, porque no contaba con muchos excedentes para el tráfico Sólo realizaba un intercambio limitado con las vecinas Paraguay y Misiones y se importaban algunas manufacturas desde Buenos Aires. ${ }^{7}$

Recién durante las últimas décadas del siglo XVIII el distrito experimentó un sostenido crecimiento demográfico y económico en base al desarrollo de la actividad ganadera. El progreso de la misma impulsó la ocupación de tierras baldías. Entre 1760 y 1810 , la jurisdicción correntina aumentó de $14.000 \mathrm{~km} 2$ a cerca de $50.000 \mathrm{~km} 2$ con la incorporación de la cuenca del Iberá y las áreas al sur del río Corrientes. En ese mismo

\footnotetext{
${ }^{6}$ Existe una lista completa de precios de efectos importados y frutos del país en la ciudad de Corrientes publicada por órdenes del gobierno en los meses de abril y mayo de 1848 en el periódico Corrientes Confederada. Este registro es excepcional y sólo se encuentra otro similar en El Comercio para 1855.

${ }^{7}$ Ernesto J.A. Maeder, Historia económica de Corrientes en el periodo virreinal. 1776-1810, Buenos Aires, Academia Nacional de la Historia, 1981, cap. I.
} 
lapso la población creció de alrededor de 9.000 habitantes a unos 30.000 pobladores.

El auge ganadero promovió una mayor especialización productiva. El distrito contó además con los bienes necesarios para el desarrollo del tráfico con otras comarcas. Estas posibilidades comerciales se ampliaron con las reformas borbónicas que suprimían algunas trabas a los intercambios. Éstas, como es sabido, consolidaron la posición hegemónica de Buenos Aires en su calidad de nexo con los mercados de ultramar. Sin embargo, en las etapas iniciales del auge ganadero correntino las exportaciones se orientaron fundamentalmente hacia las comarcas vecinas del Paraguay y Misiones. Para ambos distritos se remitía ganado en pie a cambio de yerba y lienzos. ${ }^{8}$

\section{Gráfico $\mathrm{n}^{0} 1$ Evolución del comercio de Corrientes (por quinquenios)}

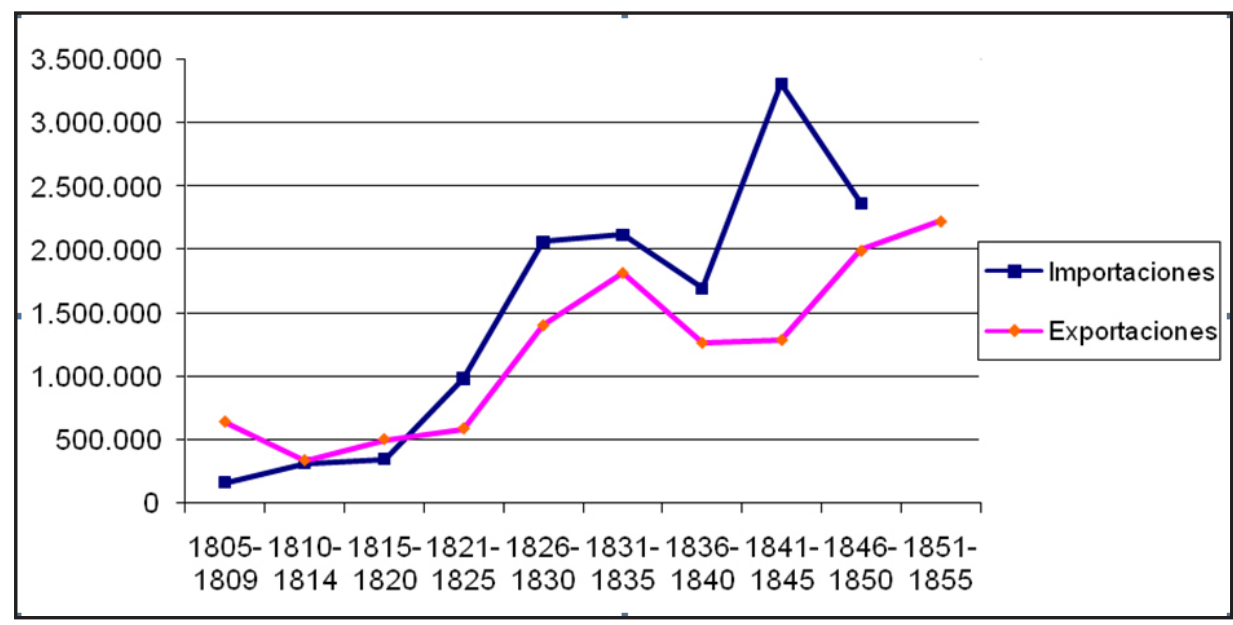

Cuadro $\mathbf{n}^{0}$ 1. Valor del comercio exterior de la provincia del Corrientes (1805-1855). En pesos plata

\begin{tabular}{|l|l|l|}
\hline & Importaciones & Exportaciones \\
\hline 1805 & 53.483 & $144.385[\mathbf{5 8 . 2 5 9}]$ \\
1806 & 29.114 & $88.287[\mathbf{6 0 . 9 1 1}]$ \\
1807 & 12.630 & $114.294[\mathbf{7 2 . 1 8 9 ]}$ \\
1808 & 18.953 & $119.706[\mathbf{7 9 . 1 6 2}]$ \\
1809 & 48.560 & $174.711[\mathbf{1 4 2 . 6 1 8}]$ \\
1810 & 57.650 & 100.628 \\
1811 & 42.225 & 76.990 \\
1812 & 63.400 & 40.666 \\
1813 & 79.950 & 76.758 \\
1814 & 66.400 & 40.721 \\
1815 & $\mathrm{~s} / \mathrm{d}$ & 100.359 \\
1816 & 58.683 & 144.363 \\
1817 & 84.488 & 122.000 \\
1818 & 79.122 & 80.209 \\
\cline { 2 - 3 } & &
\end{tabular}

\footnotetext{
${ }^{8}$ Ernesto J. A. Maeder, Ibid., capítulos. II y VI.
} 


\begin{tabular}{|c|c|c|}
\hline & Importaciones & Exportaciones \\
\hline 1819 & 52.601 & 78.022 \\
\hline 1820 & 69.419 & 78.226 \\
\hline 1821 & 109.584 & 65.015 \\
\hline 1822 & 29.941 & 164.682 \\
\hline 1823 & 383.066 & 185.558 \\
\hline 1824 & $\mathrm{~s} / \mathrm{d}$ & 106.285 \\
\hline 1825 & 357.624 & 172.232 \\
\hline 1826 & 391.074 & 258.322 \\
\hline 1827 & 385.411 & 286.879 \\
\hline 1828 & 196.801 & 206.550 \\
\hline 1829 & 626.448 & 411.203 \\
\hline 1830 & 462.934 & 241.967 \\
\hline 1831 & 349.008 & 322.287 \\
\hline 1832 & 426.243 & 332.325 \\
\hline 1833 & 407.147 & 374.832 \\
\hline 1834 & 394.953 & 334.733 \\
\hline 1835 & 540.279 & 455.809 \\
\hline 1836 & 399.967 & 435.387 \\
\hline 1837 & 502.511 & 350.183 \\
\hline 1838 & 308.640 & 213.088 \\
\hline 1839 & 96.779 & 64.221 \\
\hline 1840 & 387.991 & 202.987 \\
\hline 1841 & 397.076 & 314.175 \\
\hline 1842 & 463.611 & 226.430 \\
\hline 1843 & 597.319 & 408.691 \\
\hline 1844 & 601.975 & 140.407 \\
\hline 1845 & 1.250 .631 & 199.483 \\
\hline 1846 & 768.349 & 724.523 \\
\hline 1847 & 509.957 & 494.006 \\
\hline 1848 & 410.501 & 221.647 \\
\hline 1849 & 355.054 & 297.477 \\
\hline 1850 & 323.495 & 258.268 \\
\hline 1851 & 328.633 & 590.672 \\
\hline 1852 & 335.776 & 264.978 \\
\hline 1853 & 428.100 & 443.985 \\
\hline 1854 & $\mathrm{~s} / \mathrm{d}$ & 488.448 \\
\hline 1855 & $\mathrm{~s} / \mathrm{d}$ & 439.612 \\
\hline
\end{tabular}

Fuente: Elaboración propia en base a los siguientes registros

1) Importaciones: $\underline{1805-1823}$ y $\underline{1842-1853}$ : Archivo General de la Provincia de Corrientes: Libros de Caja y guías en la serie Comprobantes Libros de Caja y Expedientes Administrativos; 1825-1841: José Carlos Chiaramonte, Mercaderes del Litoral,. Economía y sociedad en la provincia de Corrientes en la primera mitad del siglo XIX, Buenos Aires, Siglo XXI, 1991, p. 211 2) Exportaciones: 1805-1812 y 1814-1815: Claudia Wentzel "El comercio del Litoral de los Ríos", p. 206; 1805-1809: (cifras entre corchetes) cálculo en base al resumen del Tesorero Manuel Mantilla; 1813: Archivo General de la Provincia de Corrientes. Correspondencia Oficial Libro de la Recaudación del Ramo Patriótico perteneciente al año 1813, t. 6, fls 77-83; 1816-1824 y 1842-1855: Comprobantes Libros de Caja y Expedientes Administrativos; 1825-1841: José c. Chiaramonte, Mercaderes... p. 211. 
Recién en la década de 1790 se produjo la reorientación decisiva y las exportaciones de cueros hacia Buenos Aires pasaron a constituir la base del comercio exterior del distrito. El valor del mismo experimentó un fuerte crecimiento. No obstante, esta tendencia positiva experimentó fuertes oscilaciones a partir de 1797 como resultado de los conflictos internacionales en los que se involucró la Corona y que afectaron a la economía rioplatense.

Estas variaciones continuaron durante el último quinquenio del dominio español. La etapa positiva iniciada con la firma de la paz de Amiens duró hasta 1805. Luego entre 1806 y 1808 se produjo una caída relacionada con los trastornos provocados por las invasiones inglesas y la crisis del poder virreinal. En 1809 tuvo lugar una importante reactivación atribuible quizás a la apertura del puerto de Buenos Aires al comercio británico.

Al igual que lo que ocurría con el tráfico del puerto de Buenos Aires, en el comercio correntino los valores exportados son muy superiores a los que corresponden los bienes importados. Debe señalarse, sin embargo que el valor de las importaciones está calculado en base a los ingresos de alcabala de la Caja correntina cuyos registros son incompletos debido al limitado control que misma ejercía sobre las transacciones de la campaña. Esto puede apreciarse por la gran diferencia que en el período 1805-1809 existía entre el monto las exportaciones registradas por el Tesorero de Corrientes (en el cuadro se indican en corchetes) y las arribaban a Buenos Aires. ${ }^{9}$

De todas formas aún teniendo en cuenta la existencia del subregistro parece claro que el distrito recibía relativamente pocos bienes a cambio de las cantidades crecientes de frutos que exportaba. El consumo de la población se mantenía a niveles muy bajos y la economía de intercambio aún estaba poco difundida. Estas restricciones fueron agravadas por las condiciones impuestas por el sistema comercial de la colonia por el cual el sector mercantil de Buenos Aires podía imponer altos precios de los bienes importados a cambio de los frutos locales. ${ }^{10}$

En el nuevo ciclo que se inició con la revolución de Mayo y que se extiende hasta 1821, el comercio de Corrientes sufrió oscilaciones aún más acentuadas que en la etapa anterior. Estos cambios bruscos siguieron las alternativas de la lucha por la independencia y de la guerra civil en el Litoral. Así se puede comprobar una fuerte caída de las exportaciones entre 1811 y 1814 provocada por el bloqueo del puerto de Buenos Aires y el control de la ruta fluvial por parte de la flotilla realista con base en Montevideo. Aún después de la rendición de esta plaza las dificultades se prolongaron con la crisis política que acompañó la consolidación del poder de Artigas en la provincia.

Debe tenerse en cuenta, sin embargo, que, salvo para el año 1813, las cifras de las exportaciones de 1810 a 1815 son las obtenidas del trabajo de Claudia Wentzel y corresponden sólo al tráfico con Buenos Aires. Si se incluyera el comercio con otras comarcas los totales serían mayores pues, al parecer, se trató de compensar la crisis del

\footnotetext{
${ }^{9}$ Agradezco al Dr. Ernesto Maeder quien me ha facilitado una copia del resumen de las exportaciones de Corrientes para el quinquenio 1805-1809 efectuado por el Tesorero Manuel S. Mantilla.

${ }^{10}$ Tulio Halperin Donghi, Revolución y guerra. Formación de una élite dirigente en la Argentina criolla, Buenos Aires, Siglo XXI, 1972, pp. 48-49
} 
mercado porteño afianzando la vinculación con Paraguay y Misiones. Esto parece claro con los datos que se disponen del año 1813 basados en registros del Cabildo

A partir de 1815 el precario equilibrio político logrado con la autonomía y la integración a la "Liga de los Pueblos Libres" favoreció otra vez un fuerte crecimiento de las exportaciones que se mantuvo hasta 1817. Sin embargo, este incremento no podía sostenerse dado que debido las movilizaciones y el desorden en la campaña, el mismo se basaba en la destrucción del stock ganadero. Como consecuencia, en 1818 el valor de las remesas volvió declinar y se mantuvo en niveles bastante modestos hasta la conclusión de las luchas del Litoral en 1821.

En lo que se refiere a las importaciones, el promedio anual de las introducciones durante de 1810 a 1820 fue bastante superior a las de la etapa colonial. La balanza comercial tiende a equilibrarse aunque todavía se observa un predominio de las exportaciones. El crecimiento se produjo ya en el lustro de 1810-1814 cuando el comercio fluvial experimentaba grandes dificultades. Esto posiblemente resultaba de la libertad mercantil adoptada a partir de la revolución. Sin embargo, también las posibilidades de expansión de las importaciones estaban limitadas por la crisis productiva y el desorden internos. Por otra parte, la introducción de efectos de ultramar estuvo fuertemente gravada por los reglamentos aduaneros de la etapa artiguista concebidos como parte de la guerra comercial contra Buenos aires. El impuesto general a las importaciones se elevó del $4 \%$ al 25\%. Durante el breve período en que Corrientes integró la "República Entrerriana" de Francisco Ramírez (fines de1820-X1821), a los derechos generales se incorporaron otros de carácter extraordinario

Con la recuperación de 1 plena autonomía en X.1821 se inició una nueva etapa caracterizada por la tranquilidad interior y el funcionamiento regular de las instituciones. Todo ello favoreció el desenvolvimiento de las actividades agropecuarias y el poblamiento de la campaña. ${ }^{11}$

En lo que respecta a la política comercial de la nueva provincia el reglamento artiguista de 1816 fue reemplazado por otro de carácter provisorio aprobado el $1^{\circ}$.XII. 1822 . El mismo más tarde fue sustituido por la Ley General de Aranceles del 10.I.1825 que constituyó la disposición básica sobre la que se fundó el sistema aduanero correntino hasta 1851.

El período que se extiende desde principios de la década de 1820 hasta mediados del decenio siguiente constituyó una fase sumamente positiva para el comercio correntino. La tendencia general hacia el crecimiento experimentó muy pocas interrupciones, la más importante de todas fue el bloqueo de los ríos durante la guerra con el Brasil durante los años 1827 y 1828 .

Durante la década de 1820, al igual que lo ocurrido en otras regiones ganaderas, las exportaciones locales de cueros sufrieron una fuerte caída. De todas formas, la escasez de hacienda en esta fase de recuperación tuvo al parecer un efecto positivo para los productores

\footnotetext{
${ }^{11}$ Sobre la organización de Estado Correntino cfr. José C. Chiaramonte, op. cit,, segunda parte "política económica, finanzas públicas y orden social”;
} 
pues en este lapso se produjo un aumento de los precios locales de los diversos frutos pecuarios. ${ }^{12}$. Asimismo la regularización del tráfico fluvial y el aumento de la demanda de bienes particularmente a raíz de la creciente prosperidad que experimentaba la provincia de Buenos Aires dieron mayores posibilidades a los productos agrícolas, forestales y silvestres. El aislamiento del Paraguay impuesto por Gaspar Rodríguez de Francia a partir de 1820 facilitó la concurrencia del tabaco de Corrientes y afianzó el papel de la provincia como intermediaria en el comercio de yerba paraguaya.

En la década de 1830 las extracciones cueros vacunos crecieron en forma continua si bien todavía no alcanzaron los montos logrados en los años más favorables del período colonial. También aumentaron considerablemente las salidas de otros subproductos pecuarios y del tabaco correntino.

Las importaciones, por su parte, experimentaron un salto extraordinario en los inicios de la década de 1820 en gran medida favorecidas por la reducción de las tarifas aduaneras en el comercio interprovincial. En 1822, Buenos Aires, redujo los derechos a las importaciones de ultramar y eliminó gran parte de los impuestos sobre los frutos provenientes de las otras provincias. El reglamento correntino de XII.1822 por su parte estableció una disminución del derecho general del $25 \%$ al $9 \%$ para los efectos de ultramar. Este gravamen se mantuvo en la Ley General de I.1825.

Medidos en términos locales los efectos de esta reducción fueron dramáticos pues a las importaciones de 1823 triplicaron a las de 1822 y se mantuvieron en ese nivel en los años siguientes. Desde ese momento la balanza comercial correntina fue casi permanentemente deficitaria. Este desequilibrio atrajo la atención de las autoridades pues amenazaba reducir las escasas reservas de moneda metálica de la provincia. Por otra parte la llegada masiva de frutos y efectos extranjeros afectaba a algunas artesanías locales. Se estableció así la prohibición de extraer oro y plata y se aumentaron los derechos de introducción de los artículos que competían con las producciones del distrito. La política proteccionista se acentuó a principios de la década de 1830. La ley de 4.I.1831 elevó el arancel general para las mercaderías extranjeras del $9 \%$ al $12 \%$ y prohibió la introducción ropas, calzados hechos y otras confecciones. Medidas complementarias también impedían el ingreso de aguardientes y azúcares. El apogeo del proteccionismo correntino tuvo lugar en el momento en que se desarrollaban las discusiones con los representantes de Buenos Aires y las otras provincias del Litoral relativas a la organización del país y la definición de una política económica de alcance nacional. Para los representantes correntinos ambas cuestiones estaban estrechamente ligadas pues sólo a través de la creación de una autoridad nacional en la que participaran las provincias éstas podían hacer valer sus reclamos a favor de una mayor protección para sus industrias locales..$^{13}$

En conjunto, si bien las medidas proteccionistas no alcanzaron todos los resultados esperados, las mismas frenaron el crecimiento acelerado de las importaciones lo que unido

\footnotetext{
12 Informes sobre el comercio exterior durante el gobierno de Martín Rodríguez, Buenos Aires, Academia Nacional de la Historia, 1978.

${ }^{13}$ Registro Oficial de la Provincia de Corrientes, tomo III, Imprenta del Estado, 1929, p.105
} 
al aumento de las salidas de frutos locales permitió reducir considerablemente el déficit comercial durante la década de 1830 .

Las diferencias planteadas con el gobierno porteño se reavivaron a raíz del bloqueo francés al Río de la Plata en III.1838. La medida perjudicaba seriamente a la economía local y el grupo dirigente correntino consideraba que la provincia se veía injustamente afectada por un conflicto en el cual no tenía participación. La ruptura abierta se produjo a principios de 1839 y continuó casi sin interrupción hasta fines de 1847. La provincia organizó tres levantamientos contra el dictador Juan Manuel de Rosas, los cuales, luego de diversas alternativas, terminaron desastrosamente. Pero aún después la derrota de la oposición correntina la paz no fue completa porque se produjeron nuevas movilizaciones en 1849 y 1850 por el conflicto con el Paraguay y en 1851 como consecuencia del pronunciamiento de Urquiza. ${ }^{14}$

La prolongación de la lucha produjo un desgaste de los recursos humanos y productivos de la provincia por lo que prácticamente toda la década de 1840 fue una etapa de crisis económica. Durante el período más crítico de la lucha las exportaciones experimentaron violentas fluctuaciones de acuerdo con las alternativas del conflicto. Los montos del año 1839 indican la paralización económica resultante del bloqueo comercial y la invasión de la provincia tras la derrota de Pago Largo. Con la reanudación de la resistencia, encabezada en esta oportunidad por Pedro Ferré, entre 1840-42 se reabrió el tráfico pero en forma más limitada. Luego de la derrota de Arroyo Grande (XII.1842) se regularizaron las relaciones con Buenos Aires y en 1843 tuvo lugar un salto excepcional de la venta de frutos. La recuperación fue muy breve pues ya en abril de ese año se iniciaba un nuevo levantamiento al mando de Joaquín de Madariaga. Los años 1844 y 1845 fueron probablemente los más críticos del período la provincia quedó totalmente aislada de los mercados del sur.

Pese al conflicto el valor de las importaciones se mantuvo más o menos constante con lo cual el déficit comercial se acrecentó considerablemente. En ese lapso ante las dificultades por las que atravesaba el comercio y la necesidad del gobierno de contar con efectos y artículos de guerra, se adoptaron disposiciones por las cuales se reducían los derechos que gravaban el tráfico y se levantaron las restricciones a las importaciones. También hay que tener en cuenta que en 1841 la provincia había celebrado un convenio con el Paraguay, país que iniciaba su apertura comercial, por lo gran parte de las importaciones que ingresaban a Corrientes tenía como destino final a la vecina república. ${ }^{15}$ Asimismo, en los años 1844 y 1845 las importaciones alcanzaron montos excepcionales por la confiscación ordenada por el gobierno correntino (X.1844) de las cargas que transportaba una flota que desde Buenos Aires se dirigía al Paraguay.

Con la llegada de la escuadra anglo-francesa al puerto de Corrientes en II.1846 concluyó el bloqueo de la provincia. El comercio fluvial experimentó una rápida reactivación

\footnotetext{
${ }_{14}$ Para un estudio minucioso de la lucha contra Rosas desde la perspectiva correntina ver Manuel F. Mantilla, Crónica histórica de la provincia de Corrientes, Buenos Aires, Espiasse, 1929, tomo II, caps. IX-XIII

${ }_{15}$ Registro Oficial de la Provincia de Corrientes, tomo V, Imprenta del Estado, 1936, p. 29
} 
favorecida luego por la finalización del conflicto internacional y la reanudación de las vinculaciones con Buenos Aires tras la derrota del gobierno antirrosista de Madariaga.

Para la región rioplatense los años finales de la etapa rosista son considerados como un período de prosperidad económica. A partir de la década de 1840 comenzó a manifestarse la plenamente la madurez de la economía ganadera con un crecimiento excepcional de las exportaciones pecuarias de todo tipo. En este crecimiento la mayor participación correspondió a la provincia de Buenos Aires, pero también se observa el ascenso significativo de Entre Ríos. ${ }^{16}$

En el caso correntino la situación parece menos brillante. En la segunda mitad de la década de 1840, una vez concluida la fase más crítica de la lucha, la provincia estuvo en condiciones de aportar cantidades superiores de cueros vacunos y otros subproductos ganaderos a las de la etapa que precedió al conflicto. Sin embargo, estas remesas medidas en términos monetarios representaban mucho menos que las décadas de 1820 y 1830 . Posiblemente debido a la movilización y la inseguridad, la tendencia general a la reducción de los precios de los productos pecuarios de la región rioplatense fue más profunda y de mayor duración en Corrientes. A esto debe añadirse la decadencia de otros rubros como la exportación de tabaco y suelas. ${ }^{17}$

En los años 1846 y 1847 los valores del comercio exterior fueron excepcionales como resultado de la salida de las existencias acumuladas. Desde el momento en que el intercambio se desarrolló con mayor regularidad, a partir de 1848, los montos se redujeron considerablemente y se mantuvieron en un nivel bastante limitado hasta el año 1852.

Un testimonio del estancamiento comercial del período está dado por la reducción de los ingresos provenientes de los derechos de aduana, la principal fuente de recursos del Estado provincial. Ante la caída de las rentas el gobierno apeló al incremento de los impuestos al comercio exterior. La ley general de aduanas del 26.II.1851 se estableció un derecho general del $24 \%$ a la introducción de los efectos extranjeros. ${ }^{18}$

Tras la caída de Rosas se inició una nueva etapa positiva para la economía local. Sólo es posible seguir la evolución del tráfico hasta mediados de 1855 pues las aduanas provinciales pasaron a la jurisdicción nacional. A partir de 1853 se puede apreciar un significativo crecimiento del valor de las exportaciones, motivado en gran medida por una fuerte alza en el precio de los principales frutos. En esta recuperación también pudo haber influido la disminución paulatina de las tarifas aduaneras con la vigencia del Acuerdo de San

${ }_{16}$ Tulio Halperin Donghi, Historia Argentina. De la revolución de la independencia a la confederación rosista, Buenos Aires, Paidós, 1980, pp. 403-409; Miguel A. Rosal y Roberto Schmit “Del reformismo Borbónico...”, op. cit.

${ }^{17}$ Sobre los precios pecuarios Tulio Halperin Donghi "La expansión ganadera en la campaña de Buenos Aires (1810-1852)”, Desarrollo Económico, vol 3, abril-setiembre de 1963, pp. 60-67; Julio Broide, La evolución de los precios pecuarios argentinos en el periodo 1830-1850, Buenos Aires, Instituto de Economía, -Facultad de Ciencias Económicas, UBA, 1951

${ }^{18}$ Enrique C. Schaller, "Las finanzas públicas de la provincia de Corrientes durante la organización ncional (1810-1861)", Temas de historia argentina y americana, $\mathrm{n}^{\circ}$ 5, Buenos Aires, Universidad Católica Argentina, julio-diciembre 2004. 
Nicolás. Sin embargo, pese a los avances que se percibían, el valor de las exportaciones correntinas entre 1853 y 1855 era todavía sólo algo superior al de los mejores años de la década de 1830 .

\section{Las vinculaciones comerciales}

Desde sus orígenes el núcleo demográfico y económico de la provincia de Corrientes se concentró sobre la costa del río Paraná en particular en el noroeste, donde se ubicó el asentamiento original español. En el siglo XVIII la ocupación se extendió hacia las comarcas del centro y del sur y se orientó al este, hacia la costa del río Uruguay. Sin embargo, en el momento de la formación de la provincia en 1814 los distritos sobre la costa del río Uruguay todavía pertenecían a los pueblos guaraníes de la provincia de Misiones, en ese momento en plena decadencia.

Como se ha dicho, durante las primeras etapas de la ocupación hispánica el limitado intercambio se realizaba principalmente con las comarcas vecinas de Paraguay y Misiones. Con el auge ganadero se estableció una sólida relación comercial con Buenos Aires plaza que, a partir de la década de 1790, pasó a ser el destino principal de las exportaciones correntinas. En tiempos normales, la participación de la misma oscilaba, según los años, entre $60 \%$ y $80 \%$ del valor total de los frutos. De todas formas, durante todo el período colonial y los primeros años del ciclo revolucionario se mantuvo un tráfico más o menos regular con Paraguay y Misiones. El mismo tendía a ampliarse cuando surgían dificultades en la vinculación con Buenos aires, como sucedió durante los años 1806 y 1807.

El comercio del distrito se canalizaba por el río Paraná, excelente vía de comunicación que lo vinculaba con los puertos del sur y las principales localidades de la vecina provincia del Paraguay. La percepción de los impuestos se concentraba en la Tesorería de la ciudad de Corrientes por lo cual era muy difícil ejercer un adecuado control de las transacciones que se efectuaban en las zonas más alejadas del sur.

Cuadro no 2. Destino de las exportaciones (proporción del valor total)

\begin{tabular}{|c|l|l|l|c|c|c|c|c|}
\hline Años & $\begin{array}{l}\text { Buenos } \\
\text { Aires }\end{array}$ & $\begin{array}{l}\text { Prov.de } \\
\text { Abajo }\end{array}$ & La Bajada & Santa Fe & Misiones & Paraguay & Otros & $\begin{array}{l}\text { Total } \\
\text { (pesos) }\end{array}$ \\
\hline 1813 & 39,5 & & & 10,1 & 6,7 & 43,7 & & 76.758 \\
\hline 1816 & 42,3 & 50,7 & 5,3 & 0,9 & & 0,4 & 0,4 & 44.363 \\
\hline 1817 & 72,3 & 19,9 & 6,2 & 1,6 & & & & 122.000 \\
\hline 1818 & 14,7 & 84,6 & 0,3 & 0,2 & & 0,2 & & 80.209 \\
\hline 1819 & 22,9 & 68,3 & 5,3 & 2,3 & & 1,2 & & 78.022 \\
\hline 1820 & 26,8 & 64,1 & 4,9 & 0,4 & & 3,8 & & 78.226 \\
\hline 1821 & 24,7 & 54,9 & 20,4 & & & & & 65.015 \\
\hline
\end{tabular}

Fuente: Elaboración propia en base a comprobantes, libros de caja y expedientes adminsitrativos (Ver nota 4).

La documentación de la Tesorería local no proporciona información sobre el valor y destino de las exportaciones correntinas en la etapa inicial del ciclo revolucionario, entre 
1810 y 1815 . Se cuenta, no obstante, con los datos que proporciona Claudia Wentzel sobre los envíos hacia Buenos Aires. Para el año 1813 esta información puede complementarse con registros sobre el tráfico con otras comarcas efectuados por el Cabildo de la ciudad para el cobro del denominado "Ramo Patriótico". Como es sabido, en ese año, las exportaciones hacia el sur disminuyeron considerablemente. Debido a esta crisis se afianzaron las vinculaciones con Paraguay, Misiones y Santa Fe adonde se buscó canalizar parte de la producción que no tenía salida. Así mientras el valor de las exportaciones hacia el sur sumaba algo más de $\$ 30.000$ plata, las extracciones para el Paraguay llegaban a $\$ 33.500$ y hacia Misiones alcanzaban a unos $\$ 5.000$.

A partir de la vigencia de los reglamentos de Artigas además de la aduana de la ciudad de Corrientes se establecieron receptorías en las localidades de Goya y Esquina para controlar el tráfico ribereño en las zonas del sur.

Pese a los peligros y las constantes interrupciones motivados por los conflictos civiles en la etapa artiguista se acrecentó aún más la preponderancia de Buenos Aires por la decadencia de los mercados limítrofes. Debe señalarse que en las guías fluviales no siempre se establece un destino específico sino que se menciona a "Los puertos de Abajo" de todos modos resulta claro para este período que la expresión hace referencia a Buenos Aires. En conjunto en esta etapa poco más del 90\% del valor total de las exportaciones se dirigía a esta plaza. También se mantenía un comercio más o menos regular con otros puertos del Paraná, en particular La Bajada y Santa Fé. Hacia ellos se remitían generalmente frutos agrícolas y suelas.

En lo que se refiere a las comarcas vecinas, el comercio con Misiones prácticamente cesó pues esta provincia entró en la etapa final de disolución a partir de las destructivas incursiones portuguesas de 1816 y 1817. La relación con el Paraguay atravesó por diversas alternativas de rupturas y acercamientos diplomáticos, sin embargo, la vinculación se mantuvo en forma más o menos regular hasta 1821. Pero el comercio con este distrito se basaba en este período en el intercambio de yerba mate por manufacturas importadas. Por lo tanto disminuyó su importancia como mercado de los frutos correntinos. ${ }^{19}$

En la etapa de la organización provincial que se inició a fines de 1821, el sistema aduanero provincial se amplió y perfeccionó. La ciudad de Corrientes pasó a ser el asiento de la Colecturía General que tenía bajo control a los otros centros de percepción denominados receptorías de alcabalas. Para el comercio sobre el río Paraná además de los puertos de Corrientes, Goya y Esquina, en 1825 se habilitó Bella Vista. Asimismo en todas las poblaciones del interior comenzaron a funcionar receptorías de rentas que eventualmente podían expedir guías de extracción de animales. ${ }^{20}$

Una de las novedades del período fue el inicio de la vinculación mercantil con el sur del Brasil, el nordeste entrerriano y, en mucho menor medida, con la nueva república del Uruguay tras la disolución definitiva de Misiones y la ocupación correntina de las

\footnotetext{
${ }^{19}$ Hernán F. Gómez, Historia de la provincia de Corrientes. De la revolución de Mayo al Tratado del Cuadrilátero, Corrientes, Imprenta del Estado, 1928.

${ }^{20}$ José C. Chiaramonte, op. cit, pp. 147-148.
} 
tierras de la costa occidental del Uruguay. La percepción de los derechos de este tráfico correspondió a la receptoría de Curuzú Cuatiá, situada en el sureste de la provincia. Como prácticamente no existían poblaciones sobre la costa del Uruguay en XII.1830, se instalaron guardias fronterizas para control de las cargas en el Paso de Santa Ana, para el comercio con Brasil, y el Paso de los Higos, para el comercio con el Uruguay. ${ }^{21}$

\section{Cuadro n ${ }^{0}$ 3. Destino de las exportaciones. Proporción del valor total}

\begin{tabular}{|c|c|c|c|c|c|c|c|c|c|c|}
\hline Años & $\begin{array}{l}\text { Buenos } \\
\text { Aires }\end{array}$ & \begin{tabular}{|l|} 
Prov.de \\
Abajo
\end{tabular} & \begin{tabular}{|l|}
$\begin{array}{l}\text { Monte- } \\
\text { video }\end{array}$ \\
\end{tabular} & \begin{tabular}{|l|} 
La \\
Bajada
\end{tabular} & Santa Fe & $\begin{array}{l}\text { Entre } \\
\text { Ríos }\end{array}$ & Brasil & \begin{tabular}{|l|} 
Uru- \\
guay
\end{tabular} & Otros & $\begin{array}{l}\begin{array}{l}\text { Total } \\
\text { (pesos) }\end{array} \\
\end{array}$ \\
\hline 1822 & 31,7 & 65,8 & - & 1,6 & 0,5 & 0,3 & - & - & 0,7 & 164.682 \\
\hline 1823 & 43,6 & 54,9 & - & 0,2 & 1 & - & 3,2 & 0,1 & 0,3 & 185.558 \\
\hline 1824 & 70,9 & 21,1 & - & 0,3 & - & 3,2 & 4,5 & - & - & 106.285 \\
\hline 1825 & 57,4 & 36,7 & - & 3,1 & - & 3 & 1,7 & - & - & 161.759 \\
\hline 1827 & 45,9 & 51,5 & - & 1,1 & 0,8 & - & - & - & 0,8 & 212.000 \\
\hline 1828 & 48,7 & 46,7 & & 1,8 & 2,1 & - & 0,7 & - & - & 166.261 \\
\hline 1829 & 38 & 44,6 & - & 10 & 1,4 & 0,8 & 4,7 & 0,5 & - & 313.766 \\
\hline 1830 & 68,7 & 26,6 & - & 1 & 0,2 & 2,4 & 0,9 & 0,1 & 1.8 & 170.380 \\
\hline 1831 & 74,8 & 22,8 & 0,5 & - & 1,5 & - & 0,2 & 0,1 & 0.1 & 310.000 \\
\hline 1832 & 66,2 & 30,1 & - & 1,1 & 0,4 & - & 2,2 & - & - & 277.257 \\
\hline 1833 & 91,4 & 6 & 1,3 & 0,2 & 0,1 & - & 0,7 & 0,3 & - & 357.364 \\
\hline 1834 & 80,9 & 14 , & 0,1 & 0,8 & 0,3 & 3,7 & 0,2 & - & - & 285.748 \\
\hline 1835 & 74,7 & 17,4 & 0,1 & 1 & 1 & 3,4 & 2,4 & - & - & 430.000 \\
\hline 1836 & 82,6 & 16 , & 0,05 & 0,8 & - & 0,25 & 0,3 & - & - & 390.238 \\
\hline 1837 & 88,9 & 8,8 & 1,1 & 0,1 & 0,1 & 0,5 & 0,4 & - & - & 350.125 \\
\hline 1838 & 54,6 & 15,1 & 18,7 & 5,4 & - & 1,8 & 3 & - & - & 182.214 \\
\hline
\end{tabular}

Fuente: Elaboración propia (ver nota 4)

Durante este lapso no existieron trabas graves en la vinculación con las comarcas del sur. El comercio correntino se canalizaba por el río Paraná con un predominio casi absoluto de Buenos Aires como mercado de los frutos correntinos en proporciones similares a las

${ }^{21}$ Ley del 24.XII.1821, crea el cargo de Receptor de alcabalas en Curuzú Cuatiá, Registro Oficial de la Provincia de Corrientes, tomo I, 1929, p. 54; ley del 11-XII-1830 sobre el comercio de la costa del Uruguay, Registro Oficial, tomo II, 1929, p. 132. 
de etapa artiguista. Sólo hacia 1838, a raíz del bloqueo francés el puerto de Montevideo representó una alternativa a la plaza porteña. En comparación con la importancia de Buenos Aires la exportación hacia otros puertos de la costa del río Paraná sólo tenía una significación marginal.

En el sector oriental de la provincia. la actividad comercial era modesta y, en gran medida, de carácter clandestino. La región del Alto Uruguay constituía un vasto vacío demográfico y el obstáculo natural que representaban los rápidos a la altura de la localidad de Salto contribuía a aislarla de las zonas más pobladas del sur. Corrientes ingresó la cuenca del alto Uruguay entre los años 1827 y 1830 cuando logró la incorporación a de las tierras que había pertenecido a los pueblos guaraníes de las Misiones Occidentales. Inicialmente se obtuvo el dominio de la zona comprendida entre los ríos Miriñay y Aguapey con una extensión aproximada de $16.000 \mathrm{~km} 2$. En ella el único núcleo estable era el pueblo de La Cruz.

El comercio con el Brasil se fundaba en la exportación de ganado en pie, principalmente caballos y mulas y, en menor medida vacunos, a cambio de yerba mate. Sin duda gran parte de este tráfico no está registrado por las guías locales pues son numerosos los testimonios sobre la salida clandestina de hacienda. De todas formas aún teniendo en cuenta este hecho el monto del intercambio era todavía modesto. En la segunda mitad de la década de 1830 las relaciones fronterizas se complicaron por la revolución de los Farrapos. Se agravó el contrabando y fuerzas brasileñas efectuaron incursiones en la orilla occidental. $^{22}$

Otro destino del tráfico del oriente correntino era la provincia de Entre Ríos, particularmente, la zona nordeste. Hacia allí se remitían cantidades modestas de cueros y otros subproductos los que posiblemente eran luego reenviados hacia el sur. También se registran algunos envíos esporádicos hacia la república del Uruguay.

Finalmente debe señalarse que entre 1822 y 1833 la provincia mantuvo un tráfico regular con la república del Paraguay puesto que se convirtió en la intermediaria de las remisiones de yerba hacia los mercados del sur. Sin embargo, en ese comercio, estrictamente vigilado por el gobierno de Gaspar Rodríguez de Francia, dejaron de participar los frutos correntinos.

El conflicto contra Rosas alteró por unos años los circuitos comerciales que habían prevalecido en las etapas anteriores. Entre 1840 y 1847, salvo algunos breves lapsos, la vinculación entre Buenos Aires quedó rota. Corrientes debió buscar salidas alternativas para su comercio ante el bloqueo cada vez más estricto que impuso el dictador porteño a la provincia rebelde. De esta manera Montevideo reemplazó a Buenos aires como principal destino de los frutos locales. Otro recurso fue el afianzamiento de la relación con el Brasil, Paraguay y la costa oriental del Uruguay.

Al fracasar los levantamientos antirrosistas, a partir de 1848 se restablecieron los nexos tradicionales y Buenos Aires volvió a ser la plaza privilegiada del comercio local.

${ }^{22}$ Oficios de los gobernadores José Rafael Atienza (22.VII.1836) y José Berón de Astrada (30.VI.1838), Provincia de Corrientes, Honrando el Centenario de Pago Largo y la epopeya por la libertad y la constitucionalidad 1839-31 de marzo-1939, tomo II, pp. 170-172 y 222. 
De todas formas, en esa nueva etapa el intercambio con las comarcas vecinas en el sector oriental ya tenía mayor magnitud como resultado de los progresos del poblamiento y el ascenso económico del oriente entrerriano.

La mayor actividad comercial sobre con la costa del río Uruguay determinó la formación de nuevas poblaciones y la instalación de receptorías en ellas. Así a principios de 1839 se habilitó al pueblo de La Cruz para el comercio exterior de la provincia en las mismas condiciones que los puertos del Paraná. En la zona nordeste de la provincia, en las cercanías del destruido pueblo de Santo Tomé comenzó a prosperar otro centro favorecido por su participación con el tráfico de la cercana población brasileña de San Borja. Finalmente, en 1843 se fundó el pueblo de Paso de los Libres, frente la localidad brasileña de Uruguayana. ${ }^{23}$

\section{Cuadro no 4.}

\section{Destino de las exportaciones de Corrientes. Proporción del valor total}

\begin{tabular}{|c|c|c|c|c|c|c|c|c|c|c|c|}
\hline Años & \begin{tabular}{|l|} 
Buenos \\
Aires \\
\end{tabular} & \begin{tabular}{|l} 
Prov.de \\
Abajo \\
\end{tabular} & \begin{tabular}{|l|}
$\begin{array}{l}\text { Monte- } \\
\text { video }\end{array}$ \\
\end{tabular} & $\begin{array}{l}\text { La } \\
\text { Bajada } \\
\end{array}$ & $\begin{array}{l}\text { Santa } \\
\text { Fe } \\
\end{array}$ & $\begin{array}{l}\text { Entre } \\
\text { Ríos } \\
\end{array}$ & Brasil & $\begin{array}{l}\text { Uru- } \\
\text { guay }\end{array}$ & $\begin{array}{l}\text { Para- } \\
\text { guay }\end{array}$ & Otros & \begin{tabular}{|l}
$\begin{array}{l}\text { Total } \\
\text { (pesos) }\end{array}$ \\
\end{tabular} \\
\hline 1839 & 16 & 55,6 & 12,1 & 10,8 & 2,8 & & 2,5 & 0,2 & & & 64.221 \\
\hline 1840 & & 6,7 & 84 & 1,4 & & 0,6 & 1 & 4,4 & & 1,9 & 202.987 \\
\hline 1841 & & 8,7 & 71,5 & & 0,4 & & 2,1 & 17,3 & & & 314.175 \\
\hline 1842 & 1,9 & 65,6 & 5,9 & 5 & 0,5 & & 3,55 & 17,5 & & & 226.430 \\
\hline 1843 & 63,5 & 27,8 & 0,5 & & 0,05 & 4,55 & 2,1 & 1,3 & 0,2 & & 408.691 \\
\hline 1844 & & 4,9 & & & 1,8 & & 75,8 & 9,8 & 7,7 & & 140.407 \\
\hline 1845 & & 11,7 & & & 0,7 & & 83,9 & 2,3 & 1,3 & & 199.483 \\
\hline 1846 & & 25,9 & 62,1 & 0,1 & & 0,4 & 6,4 & & 0,2 & 4,8 & 724.523 \\
\hline 1847 & 1,4 & 80,2 & 2,8 & 1,1 & 0,4 & 2,4 & 8,2 & 0,05 & 0,05 & 2,8 & 494.006 \\
\hline 1848 & 43,9 & 41 & & 4 & 1 & 3,6 & 6,5 & 0,04 & 0,01 & 0,25 & 221.647 \\
\hline 1849 & 69,7 & 24,9 & & 0,3 & 0,1 & 1,7 & 3,1 & & 0,05 & 1,5 & 297.477 \\
\hline 1850 & 75,7 & 16,3 & & 0,3 & 0,6 & 2,39 & 4,3 & 0,4 & & 0,01 & 258.268 \\
\hline 1850 & 74,26 & 16,2 & & 7,8 & 0,2 & 1,45 & 0,05 & & 0,04 & & 590.672 \\
\hline 1851 & 53,6 & 37,7 & 1,3 & 1,2 & 0,5 & 4,75 & 0,05 & & 0,9 & & 264.978 \\
\hline 1852 & 19,8 & 44,1 & 14 & 0,04 & 0,8 & 4,28 & 16,1 & 0,45 & 0,15 & 1 & 443.985 \\
\hline 1854 & 44 & 35 & 7 & 0,04 & & 9,2 & 4,15 & 0,5 & 0,1 & 1,8 & 488.448 \\
\hline
\end{tabular}

Fuente: Elaboración proipa (ver nota 4).

${ }^{23}$ Sobre la formación de las poblaciones en la costa del río Uruguay: Marco Tulio Centeno, "San Juan del hormiguero. Crónica de su origen y desarrollo. Antecedentes de la refundación de Santo Tomé." Primer Encuentro de Geohistoria Regional, Corrientes, Instituto de Investigaciones Geohistóricas, 1980, pp. 98110; Hernán F. Gómez, Divisiones administrativas, judiciales y municipales de la provincia de Corrientes, Corrientes, imprenta del Estado 1929. 
En la primera etapa de la lucha contra Rosas, entre los años 1840 y 1842 , el comercio por el río Paraná tenía por destino final a Montevideo. Este tráfico fue inicialmente favorecido por la protección que brindaba la flota francesa. Al concluir el bloqueo extranjero, la navegación fue más azarosa para las naves correntinas. Debido a estas dificultades se utilizó el río Uruguay como vía alternativa hasta la localidad de Salto. Ésta recibió en los años 1841 y 1842 poco más del 17\% de los envíos desde Corrientes.

También en esta etapa se produjo el acercamiento con la república del Paraguay, la cual tras la muerte de Francia, buscaba abandonar su política de aislamiento. El 31.VII.1841 se firmó un tratado de Amistad, Comercio y Navegación, junto con otro de Límites. Los acuerdos comerciales duraron hasta 1849 y, a través de la intermediación correntina los productos paraguayos ingresaron en volúmenes crecientes en el mercado rioplatense. Este tráfico si bien en mayor escala, mantuvo las características de épocas anteriores, es decir consistía en el intercambio de frutos (en especial yerba y tabaco) a cambio de manufacturas extranjeras. ${ }^{24}$

En la primera mitad del año 1843, tras la batalla de Arroyo Grande se produjo un crecimiento extraordinario de las exportaciones hacia Buenos Aires, pero este flujo cesó a partir de octubre de ese año al triunfar un nuevo movimiento antirrosista. El gobierno porteño estableció un estricto bloqueo de las vías fluviales al que se sumó también el sitio de Montevideo. Ante la ausencia de vías alternativas sobre el Paraná el escaso comercio de los años 1844 y 1845 se orientó hacia vecina región del sur del Brasil. Las principales plazas de salida de los frutos locales fueron Paso de los Libres y Santo Tomé. Las exportaciones consistían fundamentalmente en ganado en pie para las poblaciones fronterizas, cueros y frutos del Paraguay con destino a Porto Alegre.

A partir de 1846 la ruta del Paraná recuperó su preeminencia para la provincia por la intervención de la flota anglo francesa. Entre 1846 y 1847, Montevideo fue el destino principal de las exportaciones. A partir de 1848 con la conclusión del conflicto internacional y la incorporación de la provincia al orden rosista, se restableció la vinculación regular con Buenos Aires. En contraste, en los años finales de la década de 1840 la provincia se vio involucrada en las tensiones diplomáticas de la Confederación con los Estados vecinos. Éstos motivaron en 1849 la invasión del Paraguay a la zona de Misiones con lo cual momentáneamente cesó la vinculación con este país. También declinó considerablemente el tráfico con Brasil ante la posibilidad de una guerra abierta.

Tras la caída de Rosas, el panorama de las vinculaciones comerciales se presenta algo más diversificado. El enfrentamiento entre Buenos Aires y la Confederación no parece haber producido muchos trastornos en el tráfico fluvial. Buenos Aires conservaba la preeminencia pues allí se remitía entre un 70 y $80 \%$ de las exportaciones correntinas. Sin embargo, Montevideo todavía constituía un destino de cierta importancia y aparecen nuevos puertos sobre el río Paraná, en particular, el de Rosario. En el sector de la costa del río Uruguay se reanudaron las exportaciones hacia el Brasil. Hacia esta zona se destinaban

${ }^{24}$ Sobre los tratados Julio César Chávez, El presidente López. Vida y gobierno de don Carlos, Buenos Aires, Desalma, 1968, cap. III.; Manuel F. Mantilla op. cit, p.59. 
cantidades crecientes de ganado vacuno. Más significativa fue la vinculación con el nordeste de entre Ríos hacia donde existió un flujo regular desde la segunda mitad de la década de 1840. Este tráfico estaba ligado al crecimiento de Concordia y al progreso de la industria del saladero. En la década de 1840 se remitían fundamentalmente cueros y otros subproductos, pero a partir de 1852 los envíos estuvieron integrados por vacunos y equinos

\section{Composición de las exportaciones de la provincia de Corrientes}

El comercio de exportación de Corrientes se basó en la venta de productos ganaderos. De todos ellos desde fines del siglo XVIII y hasta la segunda mitad de la centuria siguiente, el cuero vacuno constituyó el artículo más importante para el intercambio con otras regiones. En este aspecto, el tráfico exterior correntino se asemejaba al de las demás comarcas pastoriles del litoral argentino. Sin embargo, a diferencia de éstas incorporaba una mayor variedad de frutos dado que la actividad pecuaria se complementaba con el desarrollo de cultivos de clima cálido y la explotación forestal. Esta mayor diversidad de bienes ampliaba las posibilidades comerciales y permitía compensar las caídas que se producían en alguno de los rubros de exportación como sucedió a principios de la década de 1820 .

Como contrapartida, si bien la comarca compartía las potencialidades de las zonas cálidas del norte, las llanuras templadas del sur y de la vecina región chaqueña, no estaba en condiciones de aprovechar plenamente los beneficios resultantes de una especialización productiva pues no poseía las ventajas de aquéllas en cuanto fertilidad del suelo, abundancia de recursos forestales, densidad demográfica, etc. De esta forma, los principales frutos locales intervenían sólo en forma marginal en el comercio rioplatense.

En lo que se refiere a la producción ganadera, orientada hacia los mercados de ultramar, la participación relativa de Corrientes en la exportación de bienes pecuarios fue disminuyendo a medida que se desarrollaban las potencialidades de la campaña Buenos Aires y de Entre Ríos. La provincia experimentó de manera muy tardía y limitada transformaciones decisivas para la economía rioplatense como el desarrollo de la industria del saladero y los progresos en la cría del ovino. Asimismo, los productos agrícolas y sus elaboraciones (algodón, tabaco, aguardiente) destinados fundamentalmente al mercado interno debían enfrentar la concurrencia de productos similares provenientes de Brasil, Cuba o de la vecina república del Paraguay, competencia que se veía favorecida por la libertad de comercio vigente a partir de 1810.

Al examinar la composición de las exportaciones de Corrientes debe tenerse en cuenta que durante algunos períodos un importante porcentaje de las mismas estaba integrada por frutos de origen paraguayo. El intercambio de la provincia con esta República constituye un tema de características particulares que merece un estudio especial. En este trabajo sólo se tendrán en cuenta aquellos frutos de origen correntino.

A partir de la década de 1780, las exportaciones locales experimentaron un sostenido crecimiento hasta la crisis de la independencia. En el quinquenio de 1805-1809 las salidas de cueros al pelo comprendieron alrededor del 64\% del monto total con un promedio 
98.000 unidades por año. A ellas se agregaron las suelas como resultado de la actividad de las curtiembres que se instalaron en las cercanías de la ciudad cabecera a principios del siglo XIX. Esta nueva industria, que otorgaba un valor agregado a la materia prima local, experimentó un notable desenvolvimiento sobre todo en los años 1808 y 1809 en que se remitieron alrededor de 19.000 piezas por año. Así las suelas y otras elaboraciones, con cerca del 19\% constituían el segundo rubro en importancia de las exportaciones. También debe señalarse que junto con el crecimiento del comercio de cueros secos y curtidos se produjo un aumento de la venta de otros subproductos pecuarios (lana, sebo y grasa). La participación de estos bienes era todavía modesta pues comprendía sólo un 3\% del total pero en términos absolutos los montos eran muy superiores a los de las décadas de 1780 y 1790. En contraste el tráfico de ganado en pie había declinado considerablemente.

Composición de las exportaciones de la provincia de Corrientes (\% del total)

\begin{tabular}{|l|c|c|c|c|c|c|c|c|c|}
\hline Período & $\begin{array}{l}\text { Tabaco y } \\
\text { cigarros }\end{array}$ & $\begin{array}{l}\text { otros } \\
\text { prod } \\
\text { Agríc" }\end{array}$ & cueros & suelas & $\begin{array}{l}\text { Otros } \\
\text { subprod. } \\
\text { Ganad. }\end{array}$ & $\begin{array}{l}\text { Animales } \\
\text { en pie }\end{array}$ & maderas & $\begin{array}{l}\text { Prod. } \\
\text { silvestres }\end{array}$ & $\begin{array}{l}\text { Total } \\
\text { (pesos) }\end{array}$ \\
\hline $1805-1809$ & & 6,6 & 64,2 & 18,7 & 3,1 & 4,1 & 0,4 & 2,9 & 556.128 \\
$1816-1820$ & 0,4 & 5,6 & 80,6 & 7,2 & 4,5 & & 1,3 & 0,4 & 507.099 \\
$1821-1825$ & 10,4 & 2,8 & 59,1 & 14,6 & 2,7 & 2,5 & 7,6 & 0,3 & 624.431 \\
$1826-1830$ & 21,6 & 3,8 & 35,6 & 14,7 & 3,8 & 2,4 & 13 & 5 & 894.505 \\
$1831-1835$ & 24,1 & 2 & 41 & 11 & 9 & 3 & 5,5 & 4,4 & 1.612 .991 \\
$1836-1840$ & 15,5 & 1,1 & 46,3 & 8,2 & 21,8 & 2,5 & 3,5 & 1,1 & 1.142 .280 \\
$1841-1845$ & 9,3 & 0,3 & 61,3 & 7,7 & 12,5 & 7,8 & 0,9 & 0,2 & 911.382 \\
$1846-1850$ & 1,9 & 1,4 & 69,2 & 2,9 & 14,2 & 4 & 5,9 & 0,5 & 1.503 .866 \\
$1851-1855$ & 1,2 & 4,9 & 54,1 & 1,9 & 14,6 & 5 & 17,7 & 0,6 & 1.800 .911 \\
\hline
\end{tabular}

Fuente: Elaboración propia (ver nota 4).

La exportación de los frutos no ganaderos, salvo excepciones, se mantuvo estacionaria o disminuyó a partir del auge del cuero. Algunos productos agrícolas (algodón, maní, en particular) constituían un componente tradicional del comercio. En el lapso 18051809 su participación relativa era de menos del 7\%. La extracción de maderas, también era muy limitada. Debe destacarse, sin embargo, el significativo aumento de las confecciones de algodón y lana si bien ocupaban el cuarto o quinto lugar de las remisiones.

Del quinquenio inicial del período revolucionario no se tienen registros locales del comercio de exportación. De todas formas con los datos obtenidos por Claudia Wentzel provenientes de la aduana de Buenos Aires se puede apreciar que junto con la fuerte caída del tráfico hacia esa plaza en el lapso 1811-1814, también se redujo la proporción de los cueros en el flujo. Al parecer esta disminución no afectó a los frutos destinados al consumo interno por lo que creció su participación en el total. Por otra parte, de acuerdo con la información que se tiene para el año 1813, la venta de ganado en pie hacia el Paraguay experimentó una breve pero considerable recuperación alcanzando niveles similares a los de fines del siglo XVIII.

En el lapso de 1816 y 1820, las exportaciones se concentraron en la venta de cueros al pelo los cuales llegaron a representar casi el $81 \%$ de las extracciones, con un 
promedio anual de 115.000 unidades. Al mismo tiempo se produjo una crisis de las ventas de suelas y la interrupción de las extracciones de ganado en pie. En contraste, se mantuvo firme la exportación de otros subproductos pecuarios dentro de los cuales se destaca el avance significativo de las salidas de crin. Debe señalarse, también que, pese al desorden productivo también se mantuvieron más o menos constantes las remisiones de productos agrícolas y de maderas.

A partir de 1821 el comercio de frutos correntino experimentó una etapa de crecimiento que, con muy pocos altibajos, se mantuvo hasta mediados de la década de 1830. Debido a la disminución de la hacienda vacuna, el número de piezas extraídas se redujo. En el quinquenio 1821-25 se exportó un promedio de 57.000 cueros por año y en el lustro siguiente alrededor de 30.000. En el decenio de 1830 se observa una recuperación y la media se elevó en 50.000 unidades.

La crisis temporal del comercio de cueros no significó, sin embargo, la reducción del tráfico pues las condiciones económicas eran favorables para los frutos locales. El descenso fue sobradamente compensado por una valorización muy significativa de los diversos artículos del comercio, el crecimiento de rubros tradicionales y la participación de nuevos bienes. Como consecuencia la composición de tráfico correntino tuvo un carácter cada vez más diversificado.

Durante el lapso de 1826-1835, pese a que siempre conservaron el liderazgo, las salidas de cueros al pelo representaron menos de la mitad del valor de las ventas. En lo que se refiere a los otros bienes pecuarios, en ese período se intensificó la labor de las curtiembres. En la primera mitad de la década de 1830 se exportaba un promedio anual de 8.000 unidades. Asimismo, se desarrolló el aprovechamiento de otros subproductos. Dentro de ellos se destacaba la crin pero igualmente se exportaron cantidades crecientes de sebo, grasa y tasajo. El incremento de las salidas de estos últimos artículos estuvo asociado a la instalación de los primeros saladeros en la provincia en 1833. La industria, no obstante, sólo tuvo un desenvolvimiento muy limitado. Finalmente, a partir de 1822 se reanudó también la venta de ganado en pie a las comarcas vecinas. Este tráfico, sujeto a fuertes limitaciones para evitar el contrabando y la salida indiscriminada de hacienda, estuvo muy lejos de alcanzar la importancia de la etapa colonial. En conjunto la salida de bienes pecuarios de todo tipo en esta década se mantuvo en alrededor del $60 \%$ del valor exportado.

La menor participación relativa de los frutos ganaderos se debió al incremento considerable del comercio de los frutos agrícolas, forestales y silvestres. De todos ellos, se destacan sin duda el tabaco en rama y, en menor escala, los cigarros. La exportación de estos artículos de gran valor unitario comenzó a prosperar a partir de 1822 y se vio favorecida por el aislamiento del Paraguay, hasta ese momento el principal proveedor en la región. Las salidas fueron creciendo de manera más o menos constante. De unas 3000 arrobas anuales en la primera mitad de la década de 1820, a 5.000 en la segunda y unos 8.000 en el quinquenio de 1831-1835. En el lapso de 1826-1835 los envíos de tabaco ocuparon el segundo lugar en importancia con más del $20 \%$ del valor total exportado. Junto con el tabaco se continuaron remitiendo una gran variedad de de productos agrícolas. Con 
el extraordinario crecimiento del tabaco el peso de los frutos agrícolas durante las décadas de 1820 y 1830 fue muy superior al de etapas previas o posteriores.

También la exportación de maderas creció de manera significativa. La actividad forestal vivió una etapa muy favorable durante la década del '20 con un incremento excepcional en las cantidades y valores comercializados, particularmente en los años 1826 y 1827 cuando remitieron 57.000 varas y poco más de 104.000 varas respectivamente. Este rubro ocupó el cuarto lugar en el valor total. El auge forestal disminuyó durante el decenio siguiente, pero de todas formas, la extracción de maderas constituía una porción nada pequeña de las ventas a los mercados del sur con un promedio de unas 40.000 varas anuales.

Finalmente debe señalarse que si bien la exportación de pieles de animales silvestres era un componente casi permanente del tráfico local, su importancia relativa había sido casi insignificante. Esto cambió durante las décadas de 1820 y 1830 con el crecimiento excepcional de la extracción de pieles de nutria estimulada por el auge de la industria sombrerera porteña. Entre 1826 y 1835 las salidas rondaron entre el $4 \%$ y el 5\% de las remesas.

La tendencia positiva de las exportaciones correntinas desde la organización provincial concluyó en la segunda mitad de la década de 1830. Durante los años 1836 y1837 el tráfico se desarrolló regularmente pero se manifestó una fuerte caída en los precios que al parecer afectó particularmente al tabaco, las suelas y las maderas. En 1838 el comercio sufrió las consecuencias del bloqueo del puerto de Buenos Aires y al año siguiente se inicio de lucha contra Rosas. Las consecuencias del largo conflicto se manifestaron claramente en la estructura del comercio de exportación.

Desde fines de la década de 1830 y hasta mediados 1840 se produjo una fuerte caída en el valor de las remesas de aquellos bienes con valor agregado que demandaban mayores inversiones y utilización de mano de obra. El tabaco tuvo un último año favorable en 1841 y luego comenzó una fase de decadencia de la que no se pudo recuperar. Si bien en el quinquenio de 1841-1845 todavía ocupaba el tercer lugar dentro de las exportaciones su participación se había reducido a poco más del 9\%. El resto de los frutos agrícolas prácticamente desapareció del tráfico. Se acentuó el declive del comercio de suelas que ya se veía manifestando en años anteriores, También la actividad forestal y la venta de productos silvestres sufrieron una verdadera paralización.

El tráfico en esta etapa se basó cada vez más en la extracción de cueros al pelo y de otros subproductos pecuarios. El número de cueros extraídos durante la primera mitad de la década de 1840 fue cerca del doble al del decenio anterior con un promedio anual de 90.000 unidades. En términos monetarios este aumento apenas pudo compensar la caída del valor del producto. Las extracciones de crin, sebo y grasa también experimentaron alguna disminución tanto en cantidad como en su valor pero esta reducción fue menor a la de otros frutos y por ello pasaron a ocupar el segundo lugar en el valor total de las exportaciones. Finalmente, en los años en que la paralización comercial fue más intensa creció la salida de hacienda hacia el Brasil y Paraguay. 
Concluida la fase más dura de la lucha, en el quinquenio de 1846-1850 las exportaciones reiniciaron su tendencia hacia el crecimiento. Sin embargo, la provincia tardó en recuperarse de la crisis productiva pues si bien en ese lapso las cantidades remitidas se incrementaron el valor de algunos frutos alcanzó también su nivel más bajo.

Una característica del período es el aumento excepcional de la venta de cueros secos. Los montos históricos más elevados se produjeron en los años 1846 y 1847 con 428.000 y 273.000 piezas respectivamente, que representaron el $77 \%$ y el $73 \%$ del total de las salidas. Al regularizarse el comercio en los años siguientes las extracciones se redujeron pero se mantuvieron en un promedio de 120.000 unidades. Este notable crecimiento cuantitativo fue en gran medida contrarrestado por el bajo precio del producto entre 1846 y 1848. .

También progresaron a un ritmo sostenido las exportaciones de crin, sebo, grasa, lana y otros subproductos. Éstos continuaron ocupando el segundo lugar en el monto total de las exportaciones. A partir de 1848 comenzaron a funcionar las primeras graserías en la provincia. En contraste, la exportación de suelas siguió con la tendencia hacia el descenso. Asimismo la venta de ganado se mantuvo en muy pequeña escala y sufrió una interrupción durante el año 1850 a raíz de la ruptura de relaciones entre la Confederación y Brasil.

Con respecto a los frutos agrícolas también su participación fue limitada debido a la decadencia del tabaco correntino, el cual no podía sostener la competencia del producto paraguayo que en ese momento volvía a ingresar masivamente en el mercado rioplatense. En la segunda mitad de la década de 1840 las exportaciones d tabaco no superaban las 2.000 arrobas y su valor había disminuido considerablemente Otros cultivos comenzaron a prosperar pero su importancia relativa era aún muy limitada.

En este lapso, debe destacarse el crecimiento excepcional de la explotación forestal en la zona del Chaco. Las exportaciones de maderas, alrededor de 90.000 varas anuales, avanzaron hasta ocupar el tercer lugar en el tráfico de frutos.

El quinquenio de 1851 a 1855 , último del que se tiene información proveniente de las guías locales, representó para la economía correntina una etapa de recuperación y crecimiento. Al igual que lo ocurrido durante las décadas de 1820 y 1830 se observa un aumento en el valor de los principales frutos y una tendencia a una mayor variedad en la composición del flujo exportador. Pese a las pérdidas sufridas durante la década de 1840 las exportaciones pecuarias continuaron a un ritmo sostenido. Las remesas de cueros al pelo aunque menores a la etapa anterior se mantuvieron en un promedio superior a 80.000 piezas anuales. Por otra parte, en términos monetarios representaban mucho más por la fuerte recuperación del precio del producto. En conjunto en el quinquenio la venta de cueros abarcó poco más de la mitad de las exportaciones.

Asimismo, la comercialización de otros subproductos pecuarios tendió a ampliarse por el funcionamiento de saladeros y graserías. La venta de ganado en pie experimentó un breve auge en los años 1853 y 1854. El tráfico se destinaba hacia el Brasil y la vecina Entre ríos. Se insinuaba así una reorientación del comercio hacia las comarcas vecinas. 
También se puede apreciar una leve recuperación de los frutos agrícolas La decadencia de ciertos productos tradicionales como el tabaco, el maní y la caña de azúcar, fue en parte subsanado por el auge de los cítricos y un incremento de las salidas de maíz. De todas formas la participación de los bienes agrícolas en el comercio había decaído mucho si se la compara con la de inicios de la etapa provincial. En la primera mitad de la década de 1850 pese a la tendencia favorable representaban apenas poco más del $6 \%$ del valor total de las ventas.

Como en el lustro anterior la explotación forestal daba muestras de fuerte dinamismo. En el quinquenio el promedio anual de las salidas superaba las 200.000 varas. La exportación de maderas tenía un peso creciente dentro del tráfico de frutos llegando a representar cerca del $18 \%$ de valor del mismo. Pasó a ser el segundo rubro en importancia luego de la venta de cueros al pelo.

\section{Conclusiones}

El comercio exterior de la provincia de Corrientes durante la primera mitad del siglo XIX experimentó una tendencia hacia el crecimiento. Asi la provincia mantuvo una participación considerable dentro del tráfico de la región del Litoral. No obstante, en esta orientación general existieron fuertes altibajos motivados por los conflictos políticos. Luego de la crisis provocada por las luchas del ciclo artiguista hubo una etapa de crecimiento sostenido en las décadas de 1820 y 1830 a la que le siguió una fuerte depresión que abarcó casi todo el decenio de 1840. Asimismo el desempeño del comercio exterior correntino resulta modesto si lo compara con el de otras regiones pastoriles del Litoral, en particular, el de la vecina provincia de Entre Ríos que inicia un rápido ascenso a partir de la década de 1830

En lo que se refiere a los vínculos mercantiles, durante la mayor parte de la etapa estudiada el intercambio se concentró casi exclusivamente en Buenos Aires. La relación comercial con las comarcas vecinas y otros mercados alternativos estuvieron condicionados por los problemas de índole política. Un ejemplo claro de la influencia de este factor constituyó el vínculo que mantuvo la provincia con la vecina república del Paraguay. Recién en la década de 1850 comienza a insinuarse el crecimiento del intercambio con las comarcas limítrofes del Nordeste de Entre Ríos y Sur del Brasil.

$\mathrm{Al}$ igual que las otras provincias del Litoral las exportaciones de Corrientes se basaban principalmente en los bienes pecuarios, en particular los cueros vacunos sin curtir. Estos últimos frecuentemente representaban más de la mitad del valor total de las remesas. En el caso de Corrientes, sin embargo, en su momento también tuvieron una participación considerable los cueros curtidos, el tabaco y otros frutos agrícolas, mientras que los productos forestales fueron incrementando su importancia a lo largo de la etapa. Cuando el tráfico era regular la composición de las exportaciones tendía hacia una mayor diversificación mientras que en las etapas de crisis se concentraba en la venta de cueros secos. Así durante las décadas de 1820 y 1830 se destaca la importante participación que tuvieron los frutos agrícolas (por el auge del tabaco) y los productos forestales, mientras 
que durante el ciclo artiguista de 1816-1821 y el lapso las luchas contra Rosas en la década de 1840, la participación del cuero alcanzó la proporción más elevada de todo el período. Con el retorno de la paz a principios de la década de 1850 se vuelve hacia una mayor diversificación. A diferencia de la etapa anterior ésta no se basó en un crecimiento agrícola sino de la explotación forestal y la consolidación de la actividad pecuaria que permitió mayores remesas de derivados de la ganadería como sebo, grasa y tasajo.

\title{
Resumen
}

El presente trabajo pretende contribuir al mejor conocimiento de los circuitos mercantiles en la Argentina durante la etapa previa a la organización nacional. Con ese fin se analiza la evolución general del comercio exterior de Corrientes durante la primera mitad del siglo XIX. En ese lapso la economía de esa provincia experimentó grandes fluctuaciones. Tras el considerable crecimiento productivo y comercial durante el siglo XVIII una fuerte crisis afectó al sector ganadero durante la etapa revolucionaria. El nuevo equilibrio logrado en la década de 1820 pareció abrir nuevas posibilidades, sin embargo, en el desenvolvimiento de la economía rioplatense Corrientes se vio relegada a un papel cada vez más marginal sobre todo a partir del largo conflicto contra Rosas en la década de 1840 ..

Este estudio se basa en la documentación de fiscal de la provincia. En primer lugar se ha tratado de establecer el valor monetario (en pesos plata) de las exportaciones e importaciones. A partir de los montos establecidos se busca reconstruir la evolución general de este tráfico, examinar la importancia de las vinculaciones comerciales de la provincia y la composición de su flujo exportador.

$$
<\text { Corrientes }><\text { Historia }><\text { Comercio }><\text { Siglo XIX }>
$$

\begin{abstract}
This paper aims to contribute to the better knowledge of commercial circuits in Argentina before the National Organization. It analyzes the evolution of Corrientes' overall foreign trade during the first half of the nineteenth century. During that time, the economy of the province experienced large fluctuations. Following the considerable growth of production and trade in the eighteenth century, a strong crisis affected the livestock sector during the revolutionary period. The new stability achieved in the 1820 decade seemed to open new possibilities; however, in the economic growth of the Río de la Plata region, Corrientes was relegated to an increasing marginal role, particularly since the extended conflict against Rosas in the decade of 1840.
\end{abstract}

The study is based on fiscal documentation. First, it has tried to establish the monetary value (in pesos silver) of exports and imports, and then, to rebuild the overall evolution of this exchange traffic, considering the importance of the province external commercial linkages and the composition of its export flow.

$$
<\text { Corrientes }><\text { History }><\text { Commerce }><\text { XIX century }>
$$

